Max Stern seine Kunstwerke, darunter das Gemälde „Mädchen aus dem Sabinagebirge“, nie bei Lempertz versteigern lassen. Ebenfalls richtig ist die Annahme des Gerichts, dass ein jüdischer Veräußerer wie Max Stern den Besitz an dem verkauften Kunstwerk nicht freiwillig aufgegeben hat, so dass ein Dritter das Eigentum daran noch nicht einmal dann erwerben konnte, wenn ihm die Geschichte des Kunstwerks nicht bekannt war (§935 Abs. 1 BGB). Eine in Deutschland erhobene, auf § 985 BGB gestützte Herausgabeklage wird daher vermutlich nicht daran scheitern, dass der Kläger nicht Eigentümer und der Beklagte nicht unberechtigter Besitzer des betreffenden Kunstwerks ist, sondern daran, dass der Anspruch gemäß § 197 Abs. 1 Nr. 1 BGB verjährt ist. Es wäre deshalb wünschenswert, wenn diese Regelung eine Änderung dahingehend erfahren würde, dass Ansprüche auf Herausgabe von aus jüdischen Sammlungen entzogenen Kunstwerken nicht der Verjährung unterliegen.

Sabine Rudolph*

Dr. Sabine Rudolph ist Rechtsanwältin in Dresden.

\title{
Rechtsprechung
}

\section{Verfolgungsbedingte Versteigerung im Jahr 1937 als unrechtmäßige Wegnahme} United States District Court for the District of Rhode Island, Urteil vom 27. Dezember 2007 - CA 06-211ML

\section{UNITED STATES DISTRICT COURT FOR THE DISTRICT OF RHODE ISLAND}

\author{
ROBERT S. VINEBERG, MICHAEL D. \\ VINEBERG, SYDNEY FELDHAMMER, \\ as Trustees of THE DR. and MRS. STERN FOUNDATION
}

Plaintiffs,

v. $\quad$ CA $06-211 \mathrm{ML}$

\section{MARIA-LOUISE BISSONNETTE \\ and}

ESTATES UNLIMITED, INC.

Defendants.

\section{MEMORANDUM AND ORDER}

This is an action to recover personal property, for declaratory and injunctive relief, and for money damages. Plaintiffs, Robert S. Vineberg, Michael D. Vineberg, and Sydney Feldhammer, as Trustees of the Dr. and Mrs. Stern Foundation ("Plaintiffs" or "Stern Estate"), have moved for summary judgment on the replevin and conversion claims against Defendant Maria-Louise Bissonnette ("Defendant"). ${ }^{1}$

1 The Stern Estate has moved to substitute Robert S. Vineberg, Michael D. Vineberg, and Sydney Feldhammer, each of whom is a trustee of the Stern Estate, as named Plaintiffs in this proceeding. Defendant has not objected. The Court grants the Stern Estate's request to substitute the parties as named Plaintiffs.

\section{Summary Judgment}

- Summary judgment is only appropriate "if the pleadings, depositions, answers to interrogatories, and admissions on file, together with the affidavits, if any, show that there is no genuine issue as to any material fact and that the moving party is entitled to a judgment as a matter of law." Fed. R. Civ. P. 56(c). "A factual issue is genuine if it may reasonably be resolved in favor of either party and, therefore, requires the finder of fact to make a choice between the parties' differing versions of the truth at trial." DePoutot v. Raffaelly, 424 F.3d 112,117 (1st Cir. 2005) (citation and internal quotation marks omitted). A fact is "material" if it "has the capacity to sway the outcome of the litigation under the applicable law." Nat'1 Amusements, Inc. v. Town of Dedham, 43 F.3d 731, 735 (1st Cir. 1995).

The moving party bears the burden of demonstrating that no genuine issue of material fact exists. Clifford v. Barnhart, 449 F.3d 276, 280 (1st Cir. 2006)."In determining whether that burden is met, a court must view the record in the light most favorable to the nonmoving party and give that party the benefit of all reasonable inferences in its favor." Id. Once the moving party has made this preliminary showing, the nonmovant "may not rest upon the mere allegations or denials of [its] pleading," Fed. R. Civ. P. 56(e), but must "produce specific facts, in suitable evidentiary for, to ... establish the presence of a trialworthy issue."Triangle Trading Co., Inc. v. Robroy Industries, Inc., 200 F.3d 1, 2 (1st Cir. 1999) (citation and internal quotation marks omitted). "Nor may the court accept the nonmovant's subjective characterizations of events, unless the underlying events themselves are revealed." Simas v. First Citizens' Federal Credit Union, 170 F.3d 37, 50 (1st Cir. 1999). "[A]s to any essential factual element of its claim on which the nonmovant would bear the burden of proof at trial, its failure to come forward with sufficient evidence to generate a trialworthy issue warrants summary judgment to the moving party." Clifford, 449 F.3d at 280 (citation and internal quotation marks omitted). "[A]ny fact alleged in the movant's [s]tatement of [u]ndisputed [f]acts shall be 
deemed admitted unless expressly denied or otherwise controverted by a party objecting to the motion." DRI LR Cv 56(a)(3).

\section{Background}

The majority of the salient facts are undisputed. In or about 1913, Dr. Max Stern's ("Dr. Stern") father, Julius Stern, opened an art gallery in Dusseldorf, Germany. Julius Stern died in 1934, leaving the art gallery and its inventory to Dr. Stern. Dr. Stern was of Jewish descent and, under the Nuremberg laws, ${ }^{2}$ was subject to official persecution by the German government. In 1935, the Reich Chamber for the Fine Arts ("Reich Chamber"), an organization of the Nazi government, sent letters to Dr. Stern demanding that he liquidate his inventory and gallery. On or about September 13, 1937, Dr. Stern received a final order to sell his inventory immediately through a dealer approved by the Reich Chamber. ${ }^{3}$ Dr. Stern consigned most of his inventory and private collection, constituting hundreds of works, to the Lempertz Auction House ("LAH"), in Cologne, Germany. On or about November 13, 1937, LAH auctioned the items consigned to it by Dr. Stern, including the property that is the subject of the dispute in this matter, a nineteenth century painting by Franz Xaver Winterhalter entitled "Madchen aus den Sabiner Bergen" ("Girl from the Sabiner Mountains") ("the Painting"). The items consigned to LAH by Dr. Stern were sold at well below market value.

Dr. Stern fled Germany for Paris in December 1937. Upon discovering that Dr. Stern left Germany, the German government issued an order freezing his assets. Dr. Stern never received the proceeds of the LAH sale. ${ }^{4} \mathrm{Dr}$. Stern eventually left Paris to join his sister in London prior to the outbreak of World War II. Dr. Stern later emigrated to Canada and became a preeminent art collector and dealer there.

2 The Nuremberg laws "were aimed at the Jewish people" and "among other things, deprived Jews of their German citizenship . . . [and] of the right to work as doctors, dentists, lawyers, and journalists; and deprived Jews of any right to own property." Arthur S. Gold and William R. Coulson, The Nuremberg War Crimes Trials: 60 Years Later, CBA [Chicago Bar Association] Record, Feb./March 2006 at 40.

3 Adolf Hitler's "Nazi regime engaged in a systematic effort to confiscate thousands of works of art throughout Europe." Orkin v. Taylor, 487 F.3d 734, 736 (9th Cir.), cert. denied, 128 S. Ct. 491 (2007). At the end of World War II, it was estimated that 150,000 pieces of art had been looted in Western Europe and nearly 500,000 in Eastern Europe. Benjamin E. Pollock, Out of the Night and Fog: Permitting Litigation to Prompt An International Resolution to Nazi-Looted Art Claims, 43 Hous. L. Rev. 193 (2006). "Being associated with great works of art became another characteristic defining the Aryan conception of moral, intellectual and genetic superiority, and looted artworks were considered trophies." Kelly Diane Walton, Leave No Stone Unturned: The Search for Art Stolen by the Nazis and the Legal Rules Governing Restitution of Stolen Art, 9 Fordham Intell. Prop. Media and Ent. L.J. 549, 553 (1999). Many individuals of Jewish descent exchanged artwork for exit visas and in some rare circumstance individuals were released from concentration camps in exchange for artwork held by their families. Id. At 557.

4 One commentator has suggested that Dr. Stern had to turn over the funds and several paintings from his private collection that he had left behind in Germany to secure an exit visa for his mother. Faculty of Fine Arts, Concordia University, Auktion 392 Reclaiming the Galerie Stern, Dusseldorf, at 14 \& 24 n.57 (2006).
LAH was heavily damaged in 1943 by wartime bombing and its $\mathrm{Na}-$ zi-era records were destroyed. Post-war efforts to locate paintings from the LAH auction were hindered by the neartotal destruction of LAH records. In spite of this, after the end of World War II, Dr. Stern made numerous attempts to locate his art collection. Immediately after the war, Dr. Stern recovered some paintings through his contact with the Canadian Military Mission and also filed a claim for restitution for artwork through the British military government in post-war Germany. In 1949, Dr. Stern and his wife traveled to Europe in an attempt to locate some of his art collection. In 1948, and in 1952, Dr. Stern placed advertisements in two publications, "Canadian Art" and "Die Weltkunst". In 1958, Dr. Stern initiated proceedings in Germany for the recovery of paintings and other property seized by the Nazi government. In the early 1960's Dr. Stern pursued claims for monetary compensation for his art losses through the German restitution courts. In 1964, a court in Germany awarded Dr. Stern partial damages for his loss of profits resulting from his being forced to sell his gallery's inventory at prices that were below market value. Upon his death in 1987, Dr. Stern bequeathed all residue of his estate to the Stern Estate. The Stern Estate primarily benefits three non-profit institutions: Concordia University and McGill University in Montreal, Canada and the Hebrew University in Israel.

Dr. Karl Wilharm ("Wilharm") acquired the Painting through the LAH auction. Wilharm was Defendant's stepfather. Wilharm kept the Painting in his private collection except for one occasion, in 1954, when it was exhibited at a museum in Kassel, Germany. Defendant has had the Painting in her possession since 1959. Defendant inherited the Painting, from her mother's estate, in 1991. Defendant has resided in the United States since at least 1956 and in Rhode Island since at least 1991.

In April 2003, Estates Unlimited, Inc. ${ }^{5}$ received the Painting on consignment from Defendant. In April 2004, on behalf of the Stern Estate, the Art Loss Register ("ALR") agreed to list the lost inventory of Dr. Stern's gallery auctioned by LAH on its Holocaust related database. The Stern Estate also listed the Painting with Germany's Lost Art Internet Database. The Painting was to be auctioned by Estates Unlimited at a public auction scheduled for January 6, 2005. Just prior to the scheduled auction, however, the Stern Estate learned from ALR that the Painting was on consignment at Estates Unlimited. ALR contacted Estates Unlimited and informed Estates Unlimited of the Stern Estate's claimed ownership of the Painting. As a result, Estates Unlimited agreed to withdraw the Painting from the auction. Estates Unlimited then informed Defendant of the Stern Estate's claim of ownership.

In January 2005, the Stern Estate made a claim for restitution of the Painting with the Holocaust Claims Processing Office of the

5 Estates Unlimited, Inc., is incorporated in the State of Rhode Island with its principal place of business in Cranston. Estates Unlimited provides antique trade and estate liquidation services.

6 The Art Loss Register is the world's largest private database of lost and stolen art, antiques and collectibles. Its range of services includes item registration, search and recovery services to collectors, the art trade, insurance and worldwide law enforcement agencies. 
state of New York Banking Department ("HCPO"). ${ }^{7}$ In February 2005, HCPO sent a demand letter to Defendant through Estates Unlimited seeking restitution of the Painting. Defendant refused to return the Painting to the Stern Estate. From February 2005 through April 2006, HCPO and Defendant attempted to resolve the matter. On or about April 19, 2006, Defendant's former counsel notified the Stern Estate's counsel that the Painting had been sent to Germany "due to the institution of an action in German Courts to definitely deter-

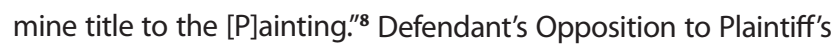
Statement of Undisputed Facts at 6. After the Painting arrived Germany, Defendant obtained an appraisal of the Painting in the range of 50,000 to 70,000 Euros (approximately $\$ 67,000$ to $\$ 94,000$ ). The instant action was instituted by the Stern Estate on May 8, 2006. The Stern Estate has moved for summary judgment against Defendant on its claims for replevin and conversion.

\section{Jurisdiction}

This case is before the Court based on diversity jurisdiction. The named Plaintiffs are trustees of the Stern Estate and are citizens of Canada. Defendant is a citizen of the state of Rhode Island. Defendant does not dispute the parties' citizenship nor does she dispute that the amount in controversy exceeds $\$ 75,000$. An exercise of this Court's diversity jurisdiction is, therefore, proper. See generally 28 U.S.C. § 1332.

\section{Choice of Law}

In a diversity action, the Court must apply the substantive law of the state in which it sits, including that state's choice of law rules. Hall v. Eklof Marine Corp., 339 F. Supp. 2 d 369 (D.R.I. 2004). The Stern Estate argues that Rhode Island law governs its replevin and conversion claims. Defendant does not address the Stern Estate's choice of law argument in its memorandum opposing summary judgment. ${ }^{9}$ A Choice of law argument not presented to the district court in a summary judgment argument is waived. Arrieta-Gimenez v. Arrieta-Negro, 859 F.2d 1033, 1037 (1st Cir. 1988); Bergin v. Dartmouth Pharmaceutical, Inc., 326 F. Supp. 2d 179, 180 n.1 (D. Mass. 2004) (court sitting in diversity jurisdiction held that choice of law argument was waived when neither party addressed it and that law of the forum state controlled claim). Accordingly, this Court need not engage is an extensive choice of law analysis and will apply Rhode Island law where appropriate.

7 In HCPO is a division of the New York State Banking Department established in 1997. Monica Dugot, The Holocaust Claims Processing Office's Handling of Art Claims, 25 Fordham Int'l L.J.133 (2001). "Its mission is to assist claimants seeking recovery of assets held in European banks, proceeds from Holocaust-era insurance policies, and lost, looted, or stolen art.” $\underline{\underline{I d}}$. at 133.

8 In the German action, Defendant informed the court that other "auction houses have also refused to accept the [P]ainting for auction in view of the recovery claims asserted. [Defendant] wishes to sell the [P]ainting by the way of auction ...." Defendant Affidavit As To Pending Suit in Cologne, Germany - Legal Action at 4. On June 12, 2007, this Court issued an order restraining Defendant from moving the Painting without prior permission from this Court.

9 In fact, it appears that Defendant agrees that Rhode Island law applies to the replevin claim as Defendant concurs with the Stern Estate's recitation of the elements of a successful replevin action.

\section{Replevin}

The Court acknowledges the highly unusual posture of this matter. Over 70 years ago, the Nazi party took art from Jewish citizens as part of a systematic plan to rob Jewish citizens of their property, their identity and, ultimately, their lives. See generally Kelly Diane Walton, 9 Fordham Intell. Prop. Media and Ent. L.J. 549. Only ten Holocaust-related suits were filed in "American courts from 1945-1995, and less than an handful of cases concerning looted art have been brought since World War II." Benjamin E. Pollock, 43 Hous. L. Rev. at 208 (citation and internal quotation marks omitted). Plaintiffs request that this Court return to the Stern Estate artwork taken from Dr. Stern pursuant to the infamous Nuremberg laws of Nazi Germany.

\section{A. Statue of Limitations}

In her answer, Defendant raised the affirmative defense of statute of limitations. In its motion for summary judgment the Stern Estate argued that it was entitled to judgment on Defendant's statute of limitations defense. The extent of Defendant's statute of limitations argument is contained in one sentence in her opposition memorandum: "[i]n defense, [Defendant] argues the equitable doctrine of laches and the legal defense of statute of limitations." Defendant's Memorandum of Law in Opposition to Plaintiff's Motion for Summary Judgment at 2. A defendant can waive the affirmative defense of statute of limitations. Heinrich v. Sweet, 44 F. Supp. $2 d 408$ (D. Mass. 1999); Narragansett Electric Co. v. Carbone, 898 A.2d 87 (R.I. 2006) (failure to plead statute of limitations results in waiver). Where a party fails to adequately develop an argument, the "district court is free to disregard" it. Higgins v. New Balance Athletic Shoe, Inc., 194 F.3d 252, 260 (1st Cir. 1999); see also United States v. Orama, 956 F. Supp. 81, 85 (D.P.R. 1997) (defendants claimed that action was time barred but cited no case law and did not develop argument, court held that because defendants raised statute of limitations defense in a "perfunctory and unsupported manner" it was waived); Jiminez v. Velcro USA, Inc., No. 01-001-JD, 2002 WL 337523 at *2 n.2 (D.N.H. March 4, 2002) (defendant stated in its motion for summary judgment that plaintiff's claims were barred by the applicable statute of limitations, however, defendant failed to develop any argument and the court did not consider statute of limitation issue); Wilkinson v. State Crime Laboratory Commission, 788 A.2d 1129, 1132 n.1 (R.I. 2002) (failure to present legal authorities and to argue error constitutes waiver of issue). This Court finds that because Defendant failed to adequately develop and argue the affirmative defense of statute of limitations in her opposition to the motion for summary judgment, the statute of limitations defense is waived. ${ }^{10}$ See generally Higgins, 194 F.3d 252.

10 The Stern Estate also moved for summary judgment with respect to Defendant's assertion of res judicata and collateral estoppel. Defendant did not address either argument in her opposition to summary judgment. Consequently, these arguments are also waived. See Higgins, 194 F. 3d 252. 


\section{B. The Merits of the Replevin Action}

Fed. R. Civ. P. 64 makes replevin available in federal court. Murphy v. Foster, F. Supp. 2d, 2007 WL 3088845 (D. Me. 2007). Pursuant to Rule 64 , replevin is available "under the circumstances and in the manner provided by the law of the state in which the district court is held, existing at the time the remedy is sought...."Fed. R. Civ. P. 64,11 Metal Forge Co. v. Vogel Tool \& Die Corp., No. 95 C 6045, 1995 WL 702628 (N.D. Illinois Nov. 27, 1995); see also Hemback v. Quickpak Corp., No. Civ. A. 97-3900, 1998 WL 54737 (E.D. Pa. Jan. 8, 1998) (rule 64 allows federal court sitting in diversity to entertain a state action on replevin and conversion). The Rhode Island statutes governing replevin are found at R.I. Gen. Laws. §§ 34-21-1-34-21-13. The Rhode Island Superior Court Rules of Civil Procedure provide that a motion for a writ of replevin shall be granted upon a showing that there is (1) a probability of a judgment being rendered in favor of the plaintiff and (2) a "substantial need for transfer of possession of the" property pending adjudication of the claim. R.I. Super. R. Civ. P. 64(a).

Replevin is an "action for the repossession of personal property wrongfully taken or detained by the defendant ...."Gem Plumbing \& Heating Co., Inc. v. Rossi, 867 A.2d 796, 806 n. 14 (R.I. 2005) (citation and internal quotation marks omitted). As noted above, in Rhode lsland, replevin is a statutory cause of action. R.I. Gen. Laws §§ 34-21-1 - 34-21-13; Brunswick Corp. v. Sposato, 389 A.2d 1251 (R.I. 1978). R.I. Gen. Laws § 34-21-1 provides, in part, that "[w]henever any goods or chattles of more than $[\$ 5,000]^{12}$ value shall be unlawfully taken or unlawfully detained from the owner or from the person entitled to possession thereof ... the owner or the other person may cause the same to be replevied by writ of replevin issuing from the superior court." R.I. Gen. Laws §34-21-1. Replevin is "available to persons claiming possession of goods or chattles either wrongfully taken or wrongfully detained. Nothing more than the right of present possession, founded upon a general or special ownership of the goods or chattels, is necessary to enable a plaintiff to maintain the action." Brunswick, 389 A.2d at 1253. "An action in replevin merely adjudicates who has the superior right to possession of goods." Associates Capital Service Corp. v. Riccardi, 408 A.2d 930, 935 (R.I. 1979) (emphasis added). The parties agree that to recover the Painting in a replevin action the Stern Estate must show that (1) it is the lawful owner of the Painting, (2) the Painting was taken from Dr. Stern, unlawfully, that is, without his permission, an (3) Defendant is in wrongful possession of the Painting. ${ }^{13}$
11 Effective December 1, 2007, Fed. R. Civ. P. 64 was amended, however, the Court looks to the language of the rule that was in effect at the time the Stern Estate filed its complaint.

12 The record reflects that the value of the Painting is in excess of $\$ 5,000$.

13 The parties also suggest that demand and refusal are required, however, in light of Brunswick, 389 A.2d at 1253, ("[n]o mention is made within chapter 21 of the necessity of a demand as a condition precedent to the institution of a replevin action, and we do not believe that such a condition ought to be read into the replevin statute"), the Court concludes that demand and refusal are not required in a replevin action.

\section{Ownership of the Painting}

In 1937, the LAH catalog for the auction of Dr. Stern's gallery inventory identified the Painting as being part of the auction. In addition to that evidence of ownership, in its 1964 decision, the restitution court in Germany cited and relied upon a list of the market value of the paintings at the Stern Gallery in 1937. That listing included the Painting. The restitution court awarded Dr. Stern compensation for lost profits on the artwork auctioned by LAH. Thus, the restitution court in Germany concluded that Dr. Stern was the owner of the Painting. At this death, Dr. Stern bequeathed all residue of his estate to the Stern Estate. The Court concludes that the Stern Estate is the lawful owner of the Painting.

\section{Unlawful Taking of the Painting}

In her opposition memorandum Defendant does not dispute the fact that the Nazi government forced Dr. Stern to liquidate inventory in his art gallery and controlled the manner of the forced sale. Dr. Stern fled the country before he realized any proceeds from the forced sale. It is clear that Dr. Stern's relinquishment of his property was anything but voluntary. In support of its claim, the Stern Estate submitted a declaration from Lynn H. Nicholas ("Nicholas"), an expert in the field of World War II history relating to the Nazi party and its activities relating to the seizure of property. Nicholas concluded that the "methods used by the Gestapo and the Nazis to force Dr. Max Stern to sell the [P]ainting ... amount to theft. Nicholas Declaration at $\uparrow 4$. “Dr. Stern's surrender of the [P]ainting to $[\mathrm{LAH}]$ for auction was ordered by the Nazi authorities and therefore the equivalent of an official seizure or a theft." ${ }^{14} \underline{\text { dd. at }}$ १ 9. In fact, the German restitution court found that the LAH auction was a "distress[ed] sale to which [Dr. Stern] was forced [to participate in] for reasons of persecution ...." Robert S. Vineberg Declaration, Ex. 15 at SE00556(a). The Nazi party's actions in this instance are therefore properly classified as looting or stealing. See generally Menzel v. List, 267 N.Y.S.2d 804, 811 (N.Y. Sup. Ct. 1966) (Nazi party could not convey good title to art taken during war because seizure of art during wartime constituted "pillage, or plunder ... [which is the] taking of private property not necessary for the immediate prosecution of [the] war effort, and is unlawful"), modified as to damages, 279 N.Y.S.2d 608 (N.Y. App. Div. 1967), rev'd as to modification, 246 N.E. 2d 742 (N.Y. 1969); see generally Stuart P. Green, Looting, Law, and Lawlessness, 81 Tul. L. Rev. 1129, 1138

14 The Stern Estate specifically relied upon the Nicholas' declaration it its motion for summary judgment. The Court is aware of two declarations, from Germany attorneys, filed by Defendant after this Court denied her motion to dismiss/stay. To the extent that these declarations raise a question of whether the Painting was stolen and/or whether the LAH auction was a forced sale, the Court finds that the declarations suffer from several infirmities. First, Defendant did not rely on the declarations or argue the issues in her oppositions to the motion for summary judgment. Consequently, any argument based on these declarations is waived. Higgins, 194 F.3d 252. Second, to the extent that the declarants discuss Dr. Stern's “willingness” with respect to the sale, the declarants do not (and cannot) speak from personal knowledge. Insight Technology, Inc. v. SureFire, LLC, No. 04-cv-74-JD, 2007 WL 3244092 at *5 (D.N.H. Nov. 1, 2007) (for "purposes of summary judgment, affidavits and declarations must be based on personal knowledge"). 
(2007) (noting that the Hague and Geneva Conventions make it a crime to take or destroy real or personal property during occupation unless it is "absolutely necessary"). The Court concludes that the Painting was taken unlawfully from Dr. Stern.

\section{Wrongful Possession of the Painting}

The Court acknowledges that Defendant acquired the Painting through no wrongdoing on her part. Defendant's predecessor-in-interest, Wilharm, however, as a result of the acquisition of the Painting through the forced sale, did not acquire good title to the Painting. "Where pillage has taken place, the title of the original owner is not extinguished." Menzel, 267 N.Y.S. 2 d at 811; James v. United States, 366 U.S. 213, 251 (1961) (Whittaker, J., concurring in part and dissenting in part) (a thief"acquires not a semblance of right, title, or interest in his plunder"); United States v. Enger, 472 F. Supp. 490, 541 \& n.20 (D.N.J. 1978) (concluding that the proposition that a thief has no "interest in the property as against the rightful owner" is "so well settled as to require no elaborate citation of authority in its support"); O'Keefe v. Snyder, 416 A.2d 862, 867 (N.J. 1980) ("generally speaking, if the paintings were stolen, the thief acquired no title and could not transfer good title to others regardless of their good faith and ignorance of the theft"); see also Hartford Accident and Indemnity Co. v. Korsak, No. C.A. 77-980, 1979 WL 200285 (R.I. Superior Court August 6, 17979) (thief does not acquire title). Legal title to the Painting remained in Dr. Stern and was transferred to the Stern Estate upon Dr. Stern's death. Because Defendant's predecessor-in-interest did not have title to the Painting, Defendant cannot lay valid claim to ownership of the Painting. This Court concludes, therefore, that Defendant is in wrongful possession of the Painting. ${ }^{15}$

\section{Laches}

Defendant argues that the doctrine of laches prevents entry of summary judgment in this matter. ${ }^{16}$ Defendants avers that there are

15 The Court is aware that replevin is a "provisional remedy that applies prior to trial on the merits. Stated differently, the replevin statute applies only when the plaintiff seek pretrial seizure of personal property pending a trial to determine ownership." Moseman Construction Co. v. State Department of Transportation, $608 \mathrm{~A} .2 \mathrm{~d}$ 34, 36 (R.I. 1992) (citation and internal quotation marks omitted). However, because the Court has concluded that, as a matter of law, the Stern Estate is the owner of the Painting, a trial on the merits to determine ownership is not necessary.

16 "The defense of laches is peculiar to courts of equity and does not apply to actions at law." Jonklaas v. Silvermann, 370 A.2d 1277, 1280 (R.I. 1977). Replevin is an action at law. Battalion Westerly Rifles v. Swan, 47 A. 1090, 1090 (R.I. 1901) ("the only remedy at law would be an action of replevin"); Moore v. Watson, 40 A. 345 (R.I. 1898). The Rhode Island Supreme Court, however, has acknowledged that although "the concept of laches originated in the courts of chancery, it is today often employed in situations in which the relief sought is not readily classifiable as equitable in nature." Raso v. Wall, 884 A. 2d 391, 394 n.8 (R.I. 2005); see also Northern Trust Co. v. Zoning Bd. Of Review, 899 A.2d 517, 520 n.6 (R.I. 2006)(declaratory judgment action sufficiently equitable in nature for application of doctrine of laches). Although the Court notes that a question exists whether the doctrine of laches applies to this matter, for the purposes of this decision, the Court assumes without deciding that the doctrine of laches applies to a replevin action. genuine issues of material fact in dispute with regard to whether Dr. Stern was diligent in pursuing the Painting. Laches is applicable when unexplained and inexcusable delay cause prejudice to the defendant. Hyszko v. Barbour, 448 A.2d 723 (R.I. 1982). A court applying the defense of laches applies a two part test: (1) there must be negligence on the part of the plaintiff that leads to a delay in the prosecution of the case, and (2) the delay must prejudice the defendant. Fitzgerald v. O'Connell, 386 A.2d 1384 (R.I. 1978). What constitutes laches depends on the circumstances of each particular case. Arcand v. Haley, 187 A.2d 142 (R.I. 1963). The prejudice may come from "loss of evidence, change of title, intervention of equities and other causes ...." Fitzgerald, 386 A.2d at 1387 (citation and internal quotation marks omitted).

Defendant argues that Dr. Stern was not diligent in pursuing the Painting. Determining reasonable or due diligence is fact sensitive and must be reviewed on a case by case basis. O'Keefe, 416 A.2d at 873. The manner in which the Painting was originally taken from Dr. Stern plays a significant role in this Court's analysis. The Court must decide whether efforts to locate the Painting were "reasonable" in a "contextual analysis" of the chaotic events of World War II in Europe and the perverse actions of the Nazi regime as directed against the Jewish population of Germany and other European countries. Autocephalous Greek-Orthodox Church of Cyprus v. Goldberg \& Feldmann Fine Arts, Inc., 917 F.2d 278, 289 (7th Cir. 1990).

Defendant argues that because the earlier efforts of Dr. Stern to locate the Painting did not include a specific reference to, or photograph of, the Painting, the Stern Estate has not demonstrated due diligence. Defendant, however, ignores the fact the Nazi regime moved to divest Dr. Stern of the inventory in his gallery in gross - and the record before the Court shows that Dr. Stern searched for the lost paintings in gross. Under these circumstances, to require that $D r$. Stern list every item lost in any attempt he made to locate artwork would be unreasonable. The "standard is not whether [Dr. Stern] did everything that might have been done with the benefit of hindsight, but whether [his] efforts were reasonable give the fact of the case." Erisoty v. Rizik, No. Civ. A. 93-6215, 1995 WL 91406 at *14 (E.D. Pa. Feb. $23,1995)$ (footnote omitted).

Defendant did not dispute the Stern Estate's fact statement that LAH was heavily damaged in 1943 by wartime bombing and its Nazi-era records were destroyed. Defendant also did not dispute the Stern Estate's statement that post-war efforts to locate the Stern Gallery paintings were severely hindered by the near total destruction of LAH records. Because these statements were not challenged, Defendant admitted them for purposes of summary judgment. See DRI LR Cv 56(3). In her statement of undisputed facts, however, Defendant asserted that "some evidence of the transactions at [LAH] survived the war." Defendant's Opposition to Plaintiff's Statement of Undisputed Facts at 7 १ 1. To support her allegation, Defendant points to the German restitution court's decision. In that decision, the German court referred to a 1961 letter from the owner of LAH in which the owner concluded that the inventory of the Stern Gallery was auctioned at "regular prices." Robert S. Vineberg Declaration, Ex. 15 at SE 00553a. Defendants thus asserts that the letter shows 
there "must have been some documentation in existence" that the LAH owner relied upon in writing the letter. Defendant's Opposition to Plaintiff's Statement of Undisputed Facts at 7 १ 1. Defendant, however, does not identify what documents she believed survived the war nor where they can be found. Additionally, Defendant does not explain to the Court how these purported documents impact the Stern Estate's specific claims. To indulge Defendant's assertions here, at best, it appears that "some" records survived the bombing, but that fact does not negate the Stern Estate's assertion that "most" of the records were destroyed. This Court therefore concludes that LAH was heavily damaged in 1943 by wartime bombing, most of its Nazi-era records were destroyed and any post-war efforts to locate the paintings from the Stern Gallery were severely hindered by the near total destruction of records that may have revealed the identities of the purchasers.

Immediately after the war ended, Dr. Stern pursued and recovered lost paintings through the Canadian Military Mission. At or about the same time, Dr. Stern pursued further recoveries through the British military government in post-war Germany. In late 1948, Dr. Stern advertised several of his lost paintings in the magazine "Canadian Art". In 1949, Dr. Stern and his wife traveled to Europe in an effort to locate lost paintings. In 1952, Dr. Stern also placed an advertisement in "Die Weltkunst."In 1958, Dr. Stern initiated proceedings in Germany for the recovery of paintings and other property seized by the Nazi government. Dr. Stern also pursued claims, and recovered damages, for his art looses through the German restitution courts in the early 1960's.

The record reflects that Dr. Stern took significant steps in attempting to make public the fact that the inventory of his gallery was taken by the Nazi party. Soon after the war, Dr. Stern used diplomatic channels, post war procedures, the press, and personal finances to locate the lost artwork. Based on the particular times and the circumstances Dr. Stern faced, he took"substantial and meaningful steps" to locate his paintings as quickly as he was reasonably and safely able to do so. Autocephalous, 917 F.2d at 290. The record also reflects that the Painting has been in the private collection of Defendant and her family for nearly seven decades, except for a relatively short time when it was placed in an exhibition at a state museum in Kassel, Germany in 1954. As a result, the Painting was not readily "susceptible to discovery" as it was not "drifting in the.. . art community ...." Eristoy, 1995 WL 91406 at *11 (E.D. Pa. Feb. 23, 1995); Cf. Toledo Museum or Art v. Ullin, 477 F. Supp. 2d 802, 808 (N.D. Ohio 2006) ("ownership and possession was public knowledge and easily discoverable"). The Court concludes that based upon the highly unusual set of circumstances in this matter, Dr. Stern took the appropriate steps and made reasonable efforts in attempting to publicize his loss and locate the inventory of his gallery.

Likewise, the Court also concludes that the Stern Estate, Dr. Stern's successor in interest, made reasonable efforts to locate the Painting. The Stern Estate contacted both the ALR and Germany's Lost Art Internet Database. On behalf of the Stern Estate, in April 2004, the ALR agreed to list the lost inventory of Dr. Stern on its Holocaust related database. In January 2005, when the Stern Estate learned from the ALR that the Painting was consigned to Estates Unlimited, the Stern Estate immediately made a claim for restitution with the HCPO. In early February 2005, one month after Stern Estate learned of the location of the Painting, the HCPO forwarded a letter to Defendant, on behalf of Stern Estate, seeking return of the Painting. Consequently, the Court concludes that Dr. Stern and the Stern Estate exercised reasonably due diligence in searching for the Painting.

Defendant's claim of laches also fails because she cannot show prejudice. Defendant argues that she was prejudice in two ways. First, Defendant argues that she has been prejudiced because , as a result of the claim, she is involved in protracted litigation that has disparaged her family name."[W]e cannot say that the expense and inconvenience of further litigation, without more, rises to the level of prejudice contemplated by the doctrine of laches." Lin Ron, Inc. v. Mann's World of Arts and Crafts Inc; 624 P.2d 1343, 1345 (Colo. Ct. App. 1981); see also Goodman v. McDonnell Douglas Corp., 606 F.2d 800 (8th Cir. 1979) (cost of litigation by itself not prejudice). Second, Defendant argues that she has changed her position because, but for the claim, it is likely that she would have sold the Painting and benefitted from the sale."The only prejudice alleged by [Defendant] is [her] inability to sell [the property] due to the pending lawsuit. This allegation simply does not rise to the level of material prejudice [in order to invoke the defense of laches]." Junkins v. Spinnaker Bay Condominium Association, No. OT-01-007, 2002 WL 337780 at *12 (Ohio Ct. App. March 1, 2002). This Court concludes that Defendant's laches argument, even if applicable, is unavailing.

In conclusion, the Court reiterates its findings:

1. The Stern Estate is the rightful owner of the Painting;

2. The Painting was taken unlawfully from Dr. Stern; and

3. Defendants is in wrongful possession of the Painting.

For the foregoing reasons, the Stern Estate's motion for summary judgment on the replevin claim is GRANTED. This Court therefore issues a writ of replevin. Defendants is ordered forthwith to turn over the Painting to the Stern Estate. ${ }^{17}$

\section{SO ORDERED.}

Mary M. Lisi

Chief United States District Judge

December 27, 2007

17 As noted, the Stern Estate's complaint also includes a claim, in the alternative, for conversion. Because the Court has granted summary judgment on the replevin claim, it need not reach the Stern Estate's conversion claim. 